\title{
Pengaruh Partisipasi Anggaran terhadap Senjangan Anggaran dengan Kemampuan Pengawas Internal sebagai Variabel Pemoderasi
}

\author{
Febryanto Hardianus Magung ${ }^{1}$ \\ I Gde Ary Wirajaya ${ }^{2}$
}

${ }^{1}$ Fakultas Ekonomi dan Bisnis Universitas Udayana (Unud), Bali, Indonesia
email: febryantomagung09@ gmail.com/Telp: 081239941263
${ }^{2}$ Fakultas Ekonomi dan Bisnis Universitas Udayana (Unud), Bali, Indonesia

\begin{abstract}
ABSTRAK
Penelitian ini ditujukan untuk memberikan bukti empiris terkait bagaimana pengaruh kemampuan pengawas internal dapat memoderasi pengaruh partisipasi anggaran terhadap senjangan anggaran. Populasi dalam penelitian ini terdiri dari para pejabat struktural di lingkungan Organisasi Perangkat Daerah (OPD) Dinas Perhubungan Pemerintahan Kota Denpasar, terdiri dari Pejabat Struktural Eselon II - IV. Teknik pengambilan sampel menggunakan metode Nonprobability Sampling khususnya Sampel Jenuh. Sampel diambil berjumlah 28 orang. Metode pengumpulan data yaitu berupa survei menggunakan kuesioner. Data diolah menggunakan program Statistical Package for Social Science (SPSS) for Windows untuk menguji hipotesis yang telah dirumuskan. Hasil uji validitas dan reliabilitas menunjukkan hasil yang dapat diterima. Hasil uji Moderated Regression Analysis (MRA) pengaruh partisipasi anggaran pada senjangan anggaran dengan kemampuan pengawas internal sebagai variabel pemoderasi, ditemukan bahwa kemampuan pengawas internal dapat memperkuat hubungan antara pengaruh partisipasi anggaran terhadap senjangan anggaran.

Kata kunci: pengawas internal, partisipasi, senjangan, anggaran
\end{abstract}

\begin{abstract}
This study aims to provide information relevant to internal internals to moderate fund accounts in budgetary slack. The population in this research is the structural officer in OPD area of Denpasar Transportation Government Department, which consist of Structural Official of Echelon II - IV. Sampling technique used in this research is Nonprobability Sampling, especially Saturated Samples. The sample used 28 people who used survey method data as questionnaire. Data is processed using the Statistical Package for Social Science (SPSS) program for windows for the hypotheses that have been formulated. Result of validity test and reliability of acceptable result. The result of Moderated Regression Analysis (MRA) analysis from budget fund to internal management as moderator variable, found that internal supervisor ability can influence budget and budget.
\end{abstract}

Keywords: internal auditors, participation, slack, budgetary

\section{PENDAHULUAN}

Asas desentralisasi yang dianut Indonesia memberikan kebebasan kepada Pemerintah Daerah (Pemda) dalam menyelenggarakan pemerintahannya masingmasing melalui kebebasan atau Otonomi Daerah. Pemerintah Daerah (Pemda) dituntut mampu memberikan pelayanan terbaik serta lebih kepada masyarakat 
melalui penerapan asas-asas pelayanan publik yang meliputi: kesamaan dan keseimbangan hak dan kewajiban, transparansi, akuntabel, partisipatif. Organisasi kebanyakan (termasuk pemerintah pusat maupun daerah) dalam menjalankan tugasnya wajib mempunyai perencanaan yang terstruktur serta menjadi pedoman dalam melaksanakan tugas. Sebagai bentuk implementasi akuntabilitas atau tanggung jawab kinerja suatu pemerintah, dibuatlah suatu kewajiban terkait pertanggungjawaban dari proses perencanaan, penyusunan dan pelaksanaan atas tugas dan fungsi pemerintah dalam upaya mewujudkan visi/ misi serta tujuan yang telah ditetapkan supaya mampu dipertanggungjawabkan kepada masyarakat yang terwujudkan melalui penetapan anggaran.

Proses penyusunan anggaran dimulai dari Kepala Daerah/Bupati/Gubernur dibantu Tim Anggaran Pemerintah Daerah (TAPD) menyusun rancangan Kebijakan Umum APBD (KUA). Rancangan Kebijakan Umum APBD (KUA) ini memuat target pencapaian kinerja yang terukur lewat program-program dan kegiatan-kegiatan yang akan segera dilaksanakan disertai dengan proyeksi pendapatan dan alokasi belanja daerah, sumber pembiayaan serta penggunaan pembiayaan itu sendiri yang disertai dengan asumsi-asumsi yang mendasarinya. Hasil Rancangan Kebijakan Umum APBD (KUA) tersebut disampaikan kepada Dewan Perwakilan Rakyat Daerah (DPRD) untuk selanjutnya dibahas dalam pembicaraan pendahuluan Rancangan Anggaran Pendapatan dan Belanja Daerah (RAPBD).

Organisasi kebanyakan menjadikan anggaran partisipasif sebagai alat utama dalam sistem pengendalian organisasi khususnya dalam proses penganggaran. 
Kemudian juga fakta bahwa hampir semua Organisasi Perangkat Daerah (OPD) disetiap pusat pemerintahan (di kota Denpasar khususnya), pasti selalu ada kesenjangan antara estimasi anggaran diatas kertas dengan realisasinya entah itu anggaran pendapatan maupun anggaran belanja. Hasil-hasil penelitian sebelumnya dilakukan oleh banyak peneliti diantaranya; Merchant (1981), Young (1985), Antie dan Eppen (1985), Lukka (1988), Siegel dan Marconi (1989), Hermanto (1998), Yuwono (1999), Little, et al., (2002), Yuhertiana (2004), Hafsah (2005), Falikhatun (2007), Andriyani dan Hidayati (2010), Novia Hapsari Ardianti (2015) menunjukkan hasil bahwa anggaran partisipatif yang tinggi dapat menyebabkan terjadinya senjangan anggaran. Berbeda dengan hasil peneitian Schift dan Lewin (1970), Camman (1976), Onsi (1973), Baiman (1982), Dunk (1993), Dunk dan Perera (1997), Wartono (1998), Minan (2005), Utomo (2006), Supanto (2010), Schoute dan Wiersma (2011), Sandrya Dewi (2013) yang menyatakan bahwa jika anggaran partisipatifnya tinggi maka akan mampu mengurangi terjadinya senjangan anggaran, sebaliknya jika anggaran partisipatifnya rendah maka dapat meningkatkan senjangan anggaran itu sendiri.

Perbedaan hasil-hasil penelitian tersebut bisa timbul karena faktor lain yang juga diduga turut memiliki andil. Ketidak konsistenan penelitian-penelitian terdahulu tersebutlah yang mendorong peneliti untuk kembali melakukan penelitian serupa terkait pengaruh partisipasi anggaran pada senjangan anggaran dengan menambahkan variabel moderasi atau variabel lainnya yang diduga memiliki pengaruh terhadap variabel bebas pada variabel terikat. Disamping partisipasi pejabat struktural, kemampuan pengawas internal saat proses penyusunan anggaran 
akan semakin menurunkan senjangan anggaran. Berdasarkan hal tersebut, penelitian ini menambahkan variabel moderasi kemampuan pengawas internal sebagai faktor kontingensi karna terkait pola perilaku, tidak berpengaruh langsung pada variabel terikat tapi berpengaruh langsung terhadap variable bebas, yang diduga memiliki pengaruh terhadap partisipasi anggaran pada senjangan anggaran. Perkembangan Anggaran Pendapatan dan Belanja Daerah (APBD) tahun anggaran 2010-2015 di Pemerintahan Kota Denpasar dan LRA (Laporan Realisasi Anggaran) OPD Dinas Perhubungan Pemerintahan Kota Denpasar Tahun Anggaran 20132015 dapat dilihat dalam Tabel 1 dan 2 berikut.

Tabel 1.

Realisasi Anggaran Pendapatan dan Belanja Daerah Kota Denpasar Tahun Anggaran 2010 - 2015 (dalam jutaan)

\begin{tabular}{lllllll}
\hline & $\begin{array}{l}\text { Anggaran } \\
\text { Pendapatan } \\
\text { Daerah (Rp.) }\end{array}$ & $\begin{array}{l}\text { Realisasi } \\
\text { Pendapatan } \\
\text { Daerah (Rp.) }\end{array}$ & $\begin{array}{l}\text { Anggaran } \\
\text { Belanja }\end{array}$ & $\begin{array}{l}\text { Realisasi } \\
\text { Daerah (Rp.) }\end{array}$ & $\begin{array}{l}\text { Belanja } \\
\text { Daerah (Rp.) }\end{array}$ & $(\%)$ \\
\hline 2010 & $1.938 .657,3$ & $2.237 .707,3$ & 115 & $2.386 .056,5$ & $1.985 .850,0$ & 83 \\
2011 & $2.395 .242,0$ & $2.662 .219,5$ & 111 & $1.997 .862,1$ & $1.660 .874,2$ & 83 \\
2012 & $3.398 .346,6$ & $3.633 .133,5$ & 107 & $2.708 .763,9$ & $2.377 .456,6$ & 88 \\
2013 & $3.763 .503,6$ & $4.109 .377,8$ & 109 & $3.361 .080,7$ & $2.741 .250,2$ & 82 \\
2014 & $4.231 .297,0$ & $4.577 .678,3$ & 109 & $5.051 .006,9$ & $4.491 .645,5$ & 89 \\
2015 & $3.975 .850,0$ & $4.535 .248,6$ & 114 & $2.026 .365,5$ & $1.864 .477,9$ & 92 \\
\hline
\end{tabular}

Sumber: Badan Pemeriksa Keuangan Republik Indonesia Perwakilan Provinsi Bali, 2017

Tabel 2.

Laporan Realisasi Anggaran OPD Dinas Perhubungan Pemerintahan Kota Denpasar Tahun Anggaran 2013-2015 (dalam jutaan)

\begin{tabular}{lllllll}
\hline Tahun & $\begin{array}{l}\text { Anggaran } \\
\text { Pendapatan } \\
\text { OPD (Rp.) }\end{array}$ & $\begin{array}{l}\text { Realisasi } \\
\text { Pendapatan } \\
\text { OPD (Rp.) }\end{array}$ & $\begin{array}{l}\text { (\%) } \\
\text { OPggaran } \\
\text { OPD (Rp) }\end{array}$ & $\begin{array}{l}\text { Realisasi } \\
\text { Belanja } \\
\text { OPD (Rp) }\end{array}$ & (\%) \\
\hline 2013 & $1.236 .205,4$ & $1.367 .257,4$ & 110 & $4.619 .461,7$ & $3.731 .092,2$ & 81 \\
2014 & $1.567 .259,3$ & $1.647 .464,8$ & 105 & $6.186 .721,1$ & $5.378 .557,1$ & 87 \\
2015 & $1.558 .456,0$ & $1.714 .427,9$ & 109 & $5.164 .364,4$ & $3.605 .908,4$ & 70 \\
\hline
\end{tabular}

Sumber: www.perhubungan.denpasarkota.go.id

Data pada Tabel 1. dan Tabel 2. mencerminkan adanya senjangan anggaran. Data pada Tabel 1. tahun 2010 contohnya; Rancangan Anggaran Pendapatan Daerah untuk kota Denpasar ditemukan bahwa realisasinya lebih besar dari yang 
dianggarkan, sedangkan pada Rancangan Anggaran Belanja Daerah realisasinya lebih kecil dari yang dianggarkan. Pola seperti ini hampir sama dengan tahun-tahun lainnya seperti yang dapat dilihat pada Tabel 1. Tidak berbeda dengan data pada Tabel 2. Rancangan Anggaran Pendapatan dan Belanja Daerah pada Organisasi Perangkat Daerah Dinas Perhubungan Pemerintahan Kota Denpasar, pada tahun 2013 contohnya; ditemukan bahwa Rancangan Anggaran Pendapatan OPD juga lebih besar realisasinya dari yang dianggarkan dan Rancangan Anggaran Belanja OPD lebih kecil realisasinya dari yang dianggarkan, begitupun dengan tahun-tahun selanjutnya. Maka dapat disimpulkan bahwa Rancangan Anggaran Pendapatan OPD serta realisasinya, realisasinya selalu lebih tinggi dari pada yang dianggarkan. Sebaliknya, Rancangan Anggaran Belanja Organisasi Perangkat Daerah dan realisasinya, terlihat realisasi selalu lebih rendah dari pada yang ditetapkan.

Berdasarkan hasil pembahasan data pada tabel tersebut, diduga bahwa Partisipasi anggaran mempengaruhi Senjangan Anggaran dengan menambahkan Kemampuan Pengawas Internal yang juga diduga mampu memoderasi pengaruh Partisipasi anggaran terhadap Senjangan Anggaran pada Organisasi Perangkat Daerah Dinas Perhubungan Pemerintahan Kota Denpasar, khususnya. Responden yang ada dalam penelitian ini yaitu para pejabat struktural yang turut andil dalam proses penyusunan anggaran yang terdiri dari Eselon II sampai dengan Eselon IV (Eselon II - Eselon IV) di lingkungan Organisasi Perangkat Daerah terkait Pemerintahan Kota Denpasar yang adalah bagian dari Tim Anggaran Pemerintah Daerah (TAPD). 
Penelitian ini menggunakan teori keagenan (agency theory) sebagai landasan teori, sebab mampu menjelaskan konsep corporate governance. Jensen dan Meckling (1976) menyebutkan agency theory sebagai konsep yang menjelaskan hubungan kontraktual prinsipal dengan agen, antara dua maupun lebih individu, kelompok maupun organisasi. Pihak prinsipal selaku pengambil keputusan dan pemberi mandat pada pihak agen dalam melakukan semua kegiatan atas nama pihak prinsipal. Inti dari teori ini adalah kontrak kerja yang didesain tepat untuk menyelaraskan kepentingan pihak prinsipal dengan pihak agen (Sinkey, 1992; Supanto, 2010).

Pihak-pihak yang terlibat dalam proses penganggaran sektor publik yaitu: eksekutif, legislatif, dan masyarakat. Hubungan keagenan dalam proses penganggaran daerah adalah: Hubungan Keagenan antara Masyarakat (Publik atau Voters) dan Legislatif, Hubungan Keagenan antara Pihak Legislatif (DPRD) dengan Pihak Eksekutif (Pemerintah Daerah) dan Hubungan Keagenan antara Kepala Daerah dengan Kepala Dinas.

Teori pendukung penelitian ini menggunakan teori kontingensi (contingency theory), karena mengasumsi berbagai pola perilaku pemimpin atau ciri dalam berbagai situasi bagi efektivitas kepemimpinan. Pendekatan kontingensi dalam perilaku organisasi adalah lingkungan yang beda menyebabkan adanya perilaku yang beda pula. Teori kontingensi mampu menghilangkan prilaku yang biasanya dianggap dilakukan berdasarkan asumsi keprilakuan dan memotivasi adanya analisis situasi sebelum diambilnya tindakan. Teori kontingensi bisa digunakan pada semua pengetahuan yang sifatnya mutakhir tentang organisasi 
dengan cara atau metode yang tepat, karena tindakan yang tepat tergantung pada variabel situasional (Davis dan Newstrom, 1985).

Anggaran merupakan rencana yang disusun secara sistematis dalam bentuk angka yang dinyatakan dalam satuan moneter serta mencakup seluruh kegiatan perusahaan dalam jangka waktu atau periode tertentu di masa mendatang. Anggaran seringkali disebut juga dengan rencana keuangan dikarnakan rencana yang disusun dinyatakan dalam bentuk unit moneter. Satuan kegiatan dan satuan uang menempati posisi penting dalam pengangaran, dalam arti segala bentuk kegiatan akan dikuantifikasikan dalam satuan uang, agar nantinya dapat diukur pencapaian efisiensi dan efektivitas atas kegiatan yang dibuat.

Penganggaran adalah komitmen resmi manajemen, terkait dengan harapan manajemen tentang pendapatan, biaya dan beragam transaksi keuangan lainnya dalam jangka waktu tertentu di masa mendatang.

Usaha-usaha perusahaan akan lebih berhasil dengan penyusunan anggaran, jika ditunjang oleh kebijakan yang terarah dan dibantu oleh perencanaan yang matang. Perusahaan yang cenderungan memandang ke depan selalu memikirkan yang mungkin dilakukan pada masa mendatang sehingga dalam pelaksanaannya, perusahaan tinggal berpegangan pada semua rencana yang telah disusun sebelumnya. Dalam perusahaan manufatktur, apabila management memperhatikan rencana untuk aktivitas-aktivitasnya di masa depan, kegiatan akan dilakukan dengan lebih efisien dengan tkeuntungan yang lebih besar. Heckerts dan Wilson mengatakan bahwa manfaat utama business budgeting adalah bisa ditentukannya kegiatan-kegiatan yang paling profitable atau bermanfaat yang akan dilakukan, 
sedangkan manfaat lainnya yaitu membantu manajer dalam mengelola perusahaan. Manajer harus mengambil keputusan-keputusan yang paling menguntungkan perusahaan, seperti memilih barang-barang atau jasa yang akan diproduksi dan dijual, memilih/menseleksi langganan, menentukan tingkat harga, metode-metode produksi, metode-metode distribusi dan termin penjualan. Budgeting mempunyai manfaat yang pada dasarnya sama, yakni dalam hal perencanaan, koordinasi, dan pengawasan.

Anggaran Pendapatan, dan Belanja Daerah (APBD), adalah rencana keuangan tahunan pemerintah daerah di Indonesia yang disetujui oleh Dewan Perwakilan Rakyat Daerah (DPRD). APBD ditetapkan dengan Peraturan Daerah (Perda) dengan jangka waktu tahun anggaran meliputi masa satu tahun, mulai dari tanggal 1 Januari sampai dengan tanggal 31 Desember yang terdiri dari:

Anggaran Pendapatan, terdiri atas; Pendapatan Asli Daerah (PAD), Bagian Dana Perimbangan, Lain-lain pendapatan yang sah, Anggaran Belanja, digunakan untuk keperluan penyelenggaraan tugas pemerintahan di daerah, Pembiayaan, yaitu setiap penerimaan yang perlu dibayar kembali dan/atau pengeluaran yang akan diterima kembali, baik pada tahun anggaran yang bersangkutan maupun tahun-tahun anggaran berikutnya. Sumber Anggaran Pendapatan dan Belanja Daerah; Retribusi, Pajak Bumi dan Bangunan, Pajak Cukai, Pajak Penghasilan.

Partisipasi merupakan suatu proses pengambilan keputusan bersama oleh dua atau lebih pihak, yang membawa efek di masa mendatang bagi mereka yang membuat atau mengambil suatu keputusan. Anggaran yang partisipatif menggambarkan keikutsertaan para manajer dalam proses penyusunan suatu 
anggaran. Keikutsertaan tersebut merupakan pendekatan yang efektif untuk perbaikan motivasi perilaku individu dalam suatu organisasi, karnanya partisipasi ini mendorong manajer berusaha lebih aktif untuk mencapai tujuan perusahaan. Hal ini sejalan dengan pendapat Murray (1988) yang menyatakan bahwa anggaran partisipatif dianggap punya konsekuensi terhadap sikap dan perilaku suatu anggota organisasi. Tingkat keterlibatan dan pengaruh seorang bawahan dalam proses penyusunan suatu anggaran merupakan faktor utama yang membedakan antara anggaran partisipatif dengan anggaran non-partisipatif.

Fungsi auditor internal pada sektor pemerintahan di Indonesia dilakukan oleh Aparat Pengawas Internal Pemerintah (APIP). Tugas APIP yang diatur dalam PP Nomor 60 Tahun 2008 ini adalah melakukan pengawasan intern yang didefinisikan sebagai seluruh proses kegiatan audit, tinjau, evaluasi, pemantauan, dan kegiatan pengawasan lain terhadap penyelenggaraan tugas dan fungsi organisasi dalam rangka memberikan keyakinan yang memadai bahwa kegiatan telah dilaksanakan sesuai dengan tolok ukur yang telah ditetapkan secara efektif dan efisien untuk kepentingan pimpinan dalam mewujudkan tata kelola pemerintahan yang baik. Pengawas Internal tidak hanya melakukan pengawasan dalam bidang keuangan namun melakukan pengawasan dalam pelaksanaan kinerja. Hal tersebut menjadikan fungsi Pengawas Internal dalam tata kelola pemerintahan sangat penting. Sesuai Peraturan Menteri Dalam Negeri Nomor 23 Tahun 2007 tentang Pedoman Tata Cara Pengawasan atas Penyelenggaraan Pemerintahan Daerah, pengawasan atas penyelenggaraan pemerintahan daerah dilaksanakan oleh Aparat Pengawas Internal Pemerintah (APIP). Aparat Pengawasan Internal 
Pemerintah (APIP) merupakan Instansi Pemerintah dengan tugas serta fungsi pokok yaitu melakukan pengawasan, terdiri dari: Badan Pengawasan Keuangan dan Pembangunan (BPKP) yang bertanggung jawab langsung pada Presiden; Inspektorat Jenderal /Inspektorat Utama /Inspektorat yang bertanggung jawab kepada Menteri/Kepala Lembaga Pemerintah Non Departemen (LPND); Inspektorat Pemerintah Provinsi yang bertanggung jawab terhadap Gubernur; Inspektorat Pemerintah Kabupaten/Kota yang bertanggung jawab terhadap Bupati/Walikota.

Menurut Belkaoui (1989), slack atau senjangan adalah kecenderungan dari organisasi atau individu untuk tidak mengoptimalkan sumber daya yang ada/tersedia dan kecenderungan untuk tidak melakukan efisiensi. Organizational slack secara mendasar mengacu pada kapasitas yang tak digunakan, sedangkan Budgetary Slack merupakan suatu proses dalam penganggaran dimana ditemukan adanya distorsi secara sengaja dengan menurunkan pendapatan yang dianggarkan dan meningkatkan biaya yang dianggarkan, (Suartana, 2010:137).

Penelitian-penelitian terdahulu tentang anggaranyang mengadopsi teori kontingensi seperti; young (1985), dunk (1993), minan (20005), hafsah (2005), latuheru (2005), sari (2006), uttomo (2006), ikhsan dan ane (2007), falikhatun (2007), pratomo dan fitri (2008), desmiyati (2009), supanto (2010), djasuli dan fadilah (2011), reysa (2011), dan hapsari (2011). Govindarajan (1986) dalam falikhatun (2007) menyatakan bahwa hasil-hasil penelitian terdahulu yang tidak konsisten dapat direkonsiliasi melalui pendekatan kontingensi. Selain itu, pendekatan kontingensi dapat digunakan untuk mengevaluasi ketidakpastian 
berbagai faktor yang mempengaruhi efektivitas penganggaran daerah. Faktor kontingensi dalam penelitian ini adalah kemampuan pengawas internal dengan hipotesis yang dihasilkan adalah sebagai berikut:

$\mathrm{H}_{1}$ : Kemampuan pengawas internal mampu memperkuat pengaruh negatif partisipasi anggaran terhadap senjangan anggaran.

\section{METODE PENELITIAN}

Desain penelitian merupakan pedoman yang berisi langkah-langkah yang akan diikuti dalam melakukan penelitian. Penelitian dilakukan berangkat dari adanya suatu permasalahan. Hipotesis kemudian ditetapkan dan penentuan variabel penelitian yang dilengkapi dengan instrumen penelitian dan desain sampel. Jenis dari penelitian ini adalah penelitian deskriptif-asosiatif dengan menggunakan pendekatan kuantitatif.

Lokasi penelitian dalam penelitian ini adalah pada Organisasi Perangkat Daerah (OPD) Dinas Perhubungan Pemerintah Kota Denpasar. Obyek pada penelitian ini adalah proses yang terdapat dalam tahapan penyusunan dan kinerja anggaran Organisasi Perangkat Daerah (OPD) Dinas Perhubungan Pemerintah Kota Denpasar, dengan melibatkan pejabat struktural Eselon II - Eselon IV yang terdapat dalam Organisasi Perangkat Daerah (OPD) Dinas Perhubungan Pemerintah Kota Denpasar, yang merupakan bagian dari Tim Anggaran Pemerintah Daerah (TAPD) periode tahun 2017.

Populasi merupakan wilayah generalisasi yang terdiri dari subyek atau obyek yang mempunyai kwalitas dan karakteristik tentang apa yang ditetapkan oleh peneliti untuk dipelajari dan kemudian ditarik kesimpulan (sugiyono, 2015:61). Populasi dalam penelitian ini adalah para pejabat struktural di lingkungan 
Organisasi Perangkat Daerah (OPD) Dinas Perhubungan Pemerintah Kota Denpasar yang masih aktif yang terdiri dari pejabat struktural eselon II sampai eselon IV.

Sampel adalah bagian dari total atau keseluruhan karakteristik yang dimiliki populasi (Sugiyono, 2015:62). Teknik pengambilan dan penentuan sampel menggunakan Nonprobability Sampling khususnya Sampel Jenuh dimana Nonprobability Sampling sendiri memiliki pengertian; tehnik pengambilan sampel yang tidak memberikan peluang atau kesempatan yang sama bagi setiap unsur atau anggota populasi untuk dipilih menjadi sampel, sedangkan Sampel Jenuh adalah teknik penentuan sampel bila semua anggota populasi digunakan sebagai sampel penelitian.

Metode pengumpulan data yang digunakan dalam penelitian ini adalah metode survei dengan memberikan kuesioner, yaitu dengan cara memberikan serangkaian pertanyaan atau pernyataan tertulis kepada responden untuk dijawab (sugiyono, 2011). Kuisioner yang disebar berisi daftar pertanyaan ataupun pernyataan tertulis terkait partisipasi pejabat struktural dalam penyusunan anggaran dan pengaruh kemampuan pengawas internal yang dalam hal ini adalah APIP (Aparat Pengawas Internal Pemerintah) dalam proses penyusunan anggaran daerah pada instansi atau bidangnya masing-masing.

Analisis regresi ditujukan agar mampu melihat seberapa besar ketergantungan suatu variabel independen dengan satu atau lebih variabel dependen, yang bertujuan mengestimasi nilai rata-rata dependen berdasarkan pada nilai variabel independen yang telah diketahui (Gujatri, 2003). Untuk dapat menguji 
hipotesis dalam penelitian ini, digunakan model pendekatan uji interaksi atau Moderated regression analysis (MRA) dengan tujuan untuk mengetahui pengaruh kemampuan pengawas internal dalam memoderasi pengaruh partisipasi anggaran pada senjangan anggaran di lingkungan Organisasi Perangkat Daerah (OPD) Dinas Perhubungan Pemerintah Kota Denpasar. Moderated Regression Analysis (MRA) merupakan aplikasi khusus regresi berganda linear dimana dalam persamaan regresinya mengandung unsur interaksi (perkalian dua atau lebih variabel independen).

Tahapan pengujian dalam penelitian diukur sebagai berikut:

Uji Statistik F (Uji Kelayakan Model) Ketepatan fungsi regresi sampel dalam menaksir nilai aktual mampu dilihat atau diukur dari Goodness of Fit-nya. Secara statistik, setidaknya pengukuran dapat dilihat dari nilai koefisien determinasi, nilai statistik F dan nilai statistik $\mathrm{t}$ (Ghozali, 2013: 97). Uji statistik F pada dasarnya menunjukkan apakah semua variabel independen atau bebas yang dimasukkan dalam persamaan atau model mempunyai pengaruh secara bersamasama terhadap variabel dependen/terikat (Ghozali, 2013;98). Uji F dilakukan dengan melihat nilai signifikansi pada tabel ANOVA, apabila nilai signifikansi $\mathrm{F} \leq$ $\alpha(0,05)$, maka model ini dikatakan layak atau variabel independen mampu menjelaskan variabel dependen.

Uji Koefisien Determinasi $\left(\mathrm{R}^{2}\right)$.Koefisien determinasi (Adjusted $R$ Square) pada intinya mengukur seberapa jauh kemampuan model dalam menerangkan variabel-variabel dependennya (Ghozali 2013:97). Nilai koefisien determinasi adalah antara nol dan satu. Nilai koefisien determinasi yang kecil berarti 
kemampuan variabel-variabel independennya dalam menjelaskan variasi variabel dependen sangat terbatas. Nilai yang mendekati satu berarti variabel-variabel independen memberikan hampir semua informasi yang dibutuhkan untuk memprediksi variasi variabel dependen.

\section{HASIL DAN PEMBAHASAN}

Statistik deskriptif ditujukan memberi gambaran atas data yang dilihat berdasarkan jumlah sampel, nilai minimum dan maksimum, nilai rata-rata atau mean, dan standar deviasi masing varabel penelitian. Berdasarkan hasil olahan SPSS 20 yang meliputi variabel partisipasi (X), kemampuan pengawas internal (Z), dan senjangan anggaran (Y), didapat hasil analisis data statistik deskriptif yang dapat dilihat pada Tabel 3. berikut.

Tabel 3.

Hasil Uji Statistik Deskriptif

\begin{tabular}{cccccc}
\hline Variabel & N & Minimum & Maximum & Mean & $\begin{array}{c}\text { Std. } \\
\text { Deviation }\end{array}$ \\
\hline X & 28 & 17,00 & 60,00 & 29,6071 & 14,985 \\
$\mathrm{Z}$ & 28 & 8,00 & 16,00 & 12,7143 & 3,12525 \\
$\mathrm{Y}$ & 28 & 5,00 & 32,00 & 18,5000 & 6,60247 \\
\hline Valid $N$ (listwise) & 28 & & & &
\end{tabular}

$\frac{\text { Valid N (listwise) }}{\text { Sumber : Data diolah, } 2017}$

Berdasarkan Tabel 3. dapat disimpulkan bahwa, jumlah pengamatan (N) penelitian ini berjumlah 28. Variabel partisipasi berdasarkan nilai pada table mempunyai nilai minimum yaitu sebesar 17,00 serta nilai maksimum yaitu sebesar 60,00 dengan nilai rata - rata yaitu sebesar 29,6071. Apabila dibagi total 10 item pertanyaan yang ada maka menghasilkan nilai yaitu sebesar 2,961. Ini berarti, kebanyakan atau rata-rata responden memberi bobot atau skor 3 untuk item pertanyaan terkait variabel partisipasi dalam penyusunan anggaran. Standar deviasi dalam hal ini merupakan gambaran seberapa jauh bervariasinya data dalam 
penelitian. Jika nilai standar deviasi jauh lebih besar terhadap nilai rata-ratanya maka nilai mean merupakan representasi yang buruk dari keseluruhan data, sebaliknya jika nilai standar deviasi jauh lebih kecil dari nilai mean, maka nilai mean dapat digunakan sebagai representasi yang baik dari keseluruhan data. Standar deviasi pada variabel partisipasi adalah sebesar 14,985. Hal ini menunjukkan bahwa standar penyimpangan data terhadap nilai rata - ratanya adalah 14,985 yang nilainya lebih kecil dari nilai rata-rata (mean) sebesar 29,6071. Ini berarti nilai mean dapat digunakan sebagai representasi dari keseluruhan data, bahwa rata-rata atau kebanyakan responden memberikan skor 3 untuk item pertanyaan atau pernyataan terkait variabel partisipasi anggaran.

Variabel kemampuan pengawas internal mempunyai nilai minimum yaitu sebesar 8,00 dan nilai maksimum yaitu sebesar 16,00 dengan mean atau nilai ratarata yaitu sebesar 12,7143. Apabila dibagi 8 item pertanyaan maka akan menghasilkan nilai yaitu sebesar 1,59 dimana berarti, rata-rata responden memberikan skor 2 untuk item pertanyaan terkait kemampuan pengawas internal sebagai variabel moderasi dalam penelitian ini. Standar deviasi dari variabel kemampuan pengawas internal yaitu sebesar 3,12525, dimana menunjukkan bahwa standar penyimpangan data terhadap nilai rata-ratanya yaitu sebesar 3,12525 yang dimana nilainya lebih kecil dari nilai rata-rata (mean) yaitu sebesar 12,7143 . Ini berarti nilai mean dapat digunakan sebagai representasi dari keseluruhan data, bahwa rata-rata atau kebanyakan responden memberikan skor 2 untuk item pertanyaan atau pernyataan terkait kemampuan pengawas internal (APIP). 
Variabel komitmen senjangan anggaran mempunyai nilai minimum yaitu sebesar 5,00 dan nilai maksimum yaitu sebesar 32,00 dengan nilai mean yaitu sebesar 18,50, apabila dibagi 5 item pertanyaan maka akan menghasilkan nilai yaitu sebesar 3,7 dimana berarti rata-rata responden memberikan skor 4 bagi item pertanyaan senjangan anggaran. Standar deviasi pada variabel senjangan anggaran memiliki nilai yaitu sebesar 6,602. Hal ini menunjukkan bahwa standar penyimpangan data terhadap nilai rata - ratanya adalah 6,602 yang nilainya lebih kecil dari nilai rata-rata (mean) sebesar 18,50. Ini berarti nilai mean dapat digunakan sebagai representasi dari keseluruhan data, bahwa rata-rata atau kebanyakan responden memberikan skor 4 untuk item pertanyaan atau pernyataan terkait senjangan anggaran.

Uji validitas digunakan untuk mengukur valid dan sahnya suatu kuesioner. Valid tidaknya sebuah kuesioner bisa dilihat dari nilai $r$ hitung yang nilainya lebih besar dari $0,30(>0,30)$ pada pearson correlation. Hasil uji validitas dalam penelitian ini bisa dilihat pada Tabel 4 .

Tabel 4. menunjukkan instrumen penelitian terkait item-item pertanyaan ataupun pernyataan yang terdapat dalam variabel partisipasi anggaran, kemampuan pengawas internal, dan senjangan anggaran adalah valid dikarenakan korelasi skor masing - masing pertanyaan dengan skor total, besar koefisien korelasinya lebih dari 0,30 . 
ISSN: 2302-8556

E-Jurnal Akuntansi Universitas Udayana Vol.25.3.Desember (2018): 2269- 2294

Tabel 4.

Hasil Uji Validitas

\begin{tabular}{|c|c|c|c|c|}
\hline No & Variabel & $\begin{array}{c}\text { Kode } \\
\text { Instrumen } \\
\end{array}$ & $\begin{array}{c}\text { Nilai Pearson } \\
\text { Correlation }\end{array}$ & Keterangan \\
\hline \multirow[t]{10}{*}{1} & Partisipasi anggaran $(\mathrm{X})$ & $\mathrm{X} .1$ & 0,719 & Valid \\
\hline & & X.2 & 0,923 & Valid \\
\hline & & X.3 & 0,843 & Valid \\
\hline & & X.4 & 0,798 & Valid \\
\hline & & X.5 & 0,898 & Valid \\
\hline & & X.6 & 0,957 & Valid \\
\hline & & X.7 & 0,929 & Valid \\
\hline & & X.8 & 0,927 & Valid \\
\hline & & X.9 & 0,787 & Valid \\
\hline & & X.10 & 0,957 & Valid \\
\hline \multirow[t]{8}{*}{2} & Kemampuan pengawas & X.1 & 0,688 & Valid \\
\hline & internal $(\mathrm{Z})$ & X.2 & 0,759 & Valid \\
\hline & & X.3 & 0,833 & Valid \\
\hline & & X.4 & 0,833 & Valid \\
\hline & & X.5 & 0,831 & Valid \\
\hline & & X.6 & 0,733 & Valid \\
\hline & & X.7 & 0,823 & Valid \\
\hline & & X.8 & 0,709 & Valid \\
\hline \multirow[t]{5}{*}{3} & Senjangan anggaran (Y) & Y.1 & 0,847 & Valid \\
\hline & & Y.2 & 0,861 & Valid \\
\hline & & Y.3 & 0,861 & Valid \\
\hline & & Y.4 & 0,671 & Valid \\
\hline & & Y.5 & 0,729 & Valid \\
\hline
\end{tabular}

Sumber: Data diolah, 2017

Kuesioner dikategorikan reliabel apabila instrumen yang digunakan beberapa kali dalam mengukur suatu objek yang sama tetap menghasilkan hasil yang konsisten dari waktu ke waktu. Uji reliabilitas ini dengan menggunakan teknik cronbach's alpha yang memiliki arti bahwa jika hasil dari crobach's alpha menghasilkan nilai alpha diatas 0,60, berarti instrumen yang digunakan dapat dikatakan reliabel. Hasil uji reliabilitas dalam penelitian ini bisa dilihat dalam Tabel 5. Berikut. 
Tabel 5.

Hasil Uji Reliabilitas

\begin{tabular}{clll}
\hline NO & Variabel & Cronbach's Alpha & Keterangan \\
\hline 1 & Partisipasi anggaran & 0,961 & Reliabel \\
2 & Kemampuan pengawas internal & 0,861 & Reliabel \\
3 & Senjangan anggaran & 0,807 & Reliabel \\
\hline Sumber $:$ Data diolah, 2017 & &
\end{tabular}

Berdasarkan Tabel 5. dapat dilihat bahwa bahwa nilai cronbach's alpha masing-masing variabel memiliki nilai lebih besar dari 0,60 . Hal ini menunjukkan bahwa semua pertanyaan dalam kuesioner penelitian ini reliabel dan dapat digunakan. Model regresi dikatakan baik apabila data yang digunakan berdistribusi normal, bebas dari heterokedastisitas, dan bebas dari multikolinearitas.

Uji normalitas bertujuan menguji model suatu regresi, yaitu apakah model regresi tersebut berdistribusi normal atau tidak. Uji normalitas pada penelitian ini menggunakan uji statistik dimana dengan menggunakan uji Kolmogorov-Smirnov (K-S). Hasil dari uji K-S ini bisa dilihat dalam Tabel 4.5 berikut ini:

Tabel 6. Hasil Uji Normalitas

\begin{tabular}{cccc}
\hline No & Persamaan & Z & $\begin{array}{c}\text { Asymp. } \\
\text { Sig. }\end{array}$ \\
\hline $1 \quad Y=\alpha+\beta_{1} X+\beta_{2} Z+\beta_{3} X * Z+e$ & 0,879 & 0,422 \\
\hline Sumber : Data diolah, 2017 & &
\end{tabular}

Berdasarkan Tabel 6. dapat dilihat bahwa nilai signifikansi dari model persamaan bernilai 0,422. Hal ini menunjukkan bahwa model persamaan memenuhi uji normalitas karena nilai Asymp. Sig. lebih besar dari 0,05.

Uji heterokedastisitas bertujuan menguji model regresi yang digunakan dalam penelitian, apakah ada perbedaan varian residual dari suatu pengamatan pada pengamatan yang lain. Uji heterokedastisitas pada penelitian ini dengan menggunakan uji statistik yaitu uji glejser yaitu dengan meregresi nilai absolute 
residual dari model yang diestimasi terhadap variabel bebas. Apabila tingkat atau nilai signifikansinya ternyata lebih besar dari 0,05 berarti tidak terjadi gejala heterokedastisitas. Hasil uji glejser bisa dilihat dalam Tabel 7. berikut.

Tabel 7.

Hasil Uji Heterokedastisitas

\begin{tabular}{|c|c|c|c|c|}
\hline No & Persamaan & Variabel & $\mathbf{t}$ & Sig. \\
\hline \multirow{3}{*}{1} & \multirow{3}{*}{$\mathrm{Y}=\alpha+\beta_{1} \mathrm{X}+\beta_{2} \mathrm{Z}+\beta_{3} \mathrm{X} * \mathrm{Z}+\mathrm{e}$} & $\bar{X}$ & $-1,618$ & 0,119 \\
\hline & & $\mathrm{Z}$ & $-1,936$ & 0,065 \\
\hline & & $\mathrm{X}^{* \mathrm{Z}}$ & 1,579 & 0,127 \\
\hline
\end{tabular}

Sumber : Data diolah, 2017

Berdasarkan Tabel 7. dapat disimpulkan bahwa nilai signifikansi variabel Partisipasi Anggaran(X), variabel Kemampuan Pengawas Internal (Z) dan interaksi antara variabel Partisipasi dengan Kemampuan Pengawas Internal (X*Z) pada model regresi memiliki nilai melebihi 0,05 , dimana menunjukkan bahwa model regresi tersebut terbebas dari gejala heterokedastisitas. Hasil analisis regresi moderasi disajikan pada Tabel 8 . berikut ini :

Tabel 8.

Hasil Analisis Regresi Moderasi

\begin{tabular}{|c|c|c|c|c|c|c|}
\hline \multirow{2}{*}{ Variabel } & & \multicolumn{2}{|c|}{ Unstandardized Coefficient } & $\begin{array}{c}\text { Standardized } \\
\text { Coefficient }\end{array}$ & \multirow{2}{*}{$\mathbf{t}$} & \multirow{2}{*}{ Sig } \\
\hline & & B & Std. Error & Beta & & \\
\hline Constant & & 3,396 & 12.334 & & .275 & .785 \\
\hline$X$ & & -.567 & .278 & -.287 & -2.040 & .032 \\
\hline $\mathrm{Z}$ & & -1.682 & .672 & -.796 & -2.503 & .026 \\
\hline X_Z & & .059 & .022 & .298 & 2.639 & .017 \\
\hline $\mathrm{R}_{\text {square }}$ & : & 0,488 & & & & \\
\hline$F_{\text {hitung }}$ & $:$ & 7,616 & & & & \\
\hline Sig. F Fitung & $:$ & 0,001 & & & & \\
\hline
\end{tabular}

Sumber: Data diolah, 2017

Pada Tabel 8. bisa dilihat nilai $F$ hitung sebesar 7,616 dengan nilai signifikansi $\mathrm{F}$ sebesar 0,001. Oleh karena nilai signifikansi $\mathrm{F}$ hitung $0,001<0,05$, 
maka model regresi linier berganda (MRA) layak digunakan untuk menguji pengaruh variabel partisipasi anggaran dan kemampuan pengawas internal pada senjangan anggaran. Artinya, variabel bebas maupun variabel pemoderasi adalah penjelas yang signifikan pada variabel terikat dalam penelitian.

Persamaan regresi dalam penelitian ini adalah:

$Y=\alpha+\beta_{1} X+\beta_{2} Z+\beta_{3} X * Z+e$

$Y=3,396-0,567 X-1,682 Z+0,059 X^{*} Z+1,691$

Berdasarkan persamaan pada model regresi moderasi diatas, dapat diketahui bahwa pada variabel partisipasi anggaran (X) memiliki nilai koefisien regresi sebesar -0,567, dan kemampuan pengawas internal (Z) sebesar -1,682. Hal itu menjelaskan bahwa variabel partisipasi anggaran dan variabel kemampuan pengawas internal memiliki pengaruh yang simbolnya negatif pada senjangan anggaran. Sedangkan interaksi antara partisipasi anggaran dengan kemampuan pengawas internal $(\mathrm{X} * \mathrm{Z})$ memiliki nilai koefisien regresi sebesar 0,059 dengan tingkat signifikansi sebesar $0,017<0,05$, berarti bahwa kemampuan pengawas internal mampu memoderasi pengaruh partisipasi anggaran pada senjangan anggaran. Sedangkan nilai $\beta$ (Beta) positif $(0,059)$ memiliki makna bahwa kemampuan pengawas internal sifatnya memperkuat pengaruh negatif partisipasi anggaran pada senjangan anggaran.

Pada Tabel 8. dapat dilihat bahwa besar nilai Adjusted $R 2$ adalah 0,488. Hal ini menunjukkan bahwa 48,8\% perubahan senjangan anggaran mampu dijelaskan oleh variabel partisipasi anggaran, serta dimoderasi oleh variabel kemampuan 
pengawas internal, sedangkan sisanya yaitu sebesar $51,2 \%$ dijelaskan oleh variabel lain di luar model.

Uji hipotesis dalam penelitian ditujukan untuk mengetahui sejauh mana pengaruh partisipasi anggaran terhadap senjangan anggaran dengan menambahkan variabel kemampuan pengawas internal sebagai variabel moderasi.

Tabel 8. menunjukkan bahwa nilai koefisien Beta ( $\beta 1)$ dari variabel partisipasi anggaran yaitu -0,567 dengan p-value yaitu sebesar 0,032<0,05, mempunyai arti; variabel partisipasi anggaran berpengaruh negatif terhadap variabel senjangan anggaran. Artinya, apabila partisipasi anggaran ditingkatkan, senjangan anggaran akan menurun. Sebaliknya, apabila partisipasi anggaran menurun, senjangan anggaran akan meningkat.

Rumusan pada hipotesis 1 yaitu "kemampuan pengawas internal mampu memperkuat pengaruh negatif partisipasi anggaran pada senjangan anggaran". Hasil dari uji Moderated Regression Analysis (MRA) dalam Tabel 4.7 menunjukkan nilai koefisien Beta $(\beta 2)$ dari variabel kemampuan pengawas internal sebesar 0,059 dengan $p$-value $0,017<0,05$, mempunyai arti bahwa variabel kemampuan pengawas internal mampu memoderasi hubungan antara variabel partisipasi anggaran pada variabel senjangan anggaran $\left(\mathrm{H}_{1}\right.$ diterima). Koefisien regresi variabel kemampuan pengawas internal atau variabel moderasi bertanda positif artinya; diinterpretasikan bahwa kemampuan pengawas internal mampu memperkuat hubungan atau pengaruh negatif antara variabel partisipasi anggaran terhadap variabel senjangan anggaran. Ini berarti bahwa kemampuan pengawas internal mampu memperkuat pengaruh negatif partisipasi anggaran pada terjadinya senjangan anggaran, dengan 
asumsi bahwa dengan adanya kemampuan pengawas internal yang baik yang dalam hal ini adalah tugas atau wewenang dari Aparat Pengawas Intern Pemerintah (APIP) selaku pengawas internal pemerintah, maka akan semakin menurunkan angka senjangan anggaran itu sendiri. Kemampuan pengawas internal merupakan quasi moderator (moderator semu) yang berhubungan langsung dengan variabel independen atau variabel prediktor yang mampu memoderasi pengaruh antara variabel partisipasi anggaran dengan variabel kesenjangan angggaran atau variabel tergantung/dependen, dimana tidak hanya berinteraksi dengan variabel prediktor/independen tetapi sekaligus berinteraksi dengan variabel tergantung/dependen yang artinya variabel kemampuan pengawas internal dapat juga menjadi variabel predictor/independen. Hal ini dapat diidentifikasi dari nilai signifikansi dari koefisien $B 2$ dan $B 3$ yang dinyatakan signifikan secara statistika $(<0,05)$.

\section{SIMPULAN}

Berdasarkan pada hasil pengujian dan pembahasan pada penelitian yang telah dilakukan ini, terkait masalah pengaruh partisipasi anggaran terhadap senjangan anggaran dengan kemampuan pengawas internal sebagai variabel pemoderasi, dapat disimpulkan sebagai berikut: Hasil uji Moderated Regression Analysis (MRA) pengaruh partisipasi anggaran pada senjangan anggaran dengan kemampuan pengawas internal sebagai variabel pemoderasi, ditemukan bahwa kemampuan pengawas internal dapat memoderasi dan memperkuat hubungan antara pengaruh partisipasi anggaran terhadap senjangan anggaran khususnya dalam Organisasi Perangkat Daerah (OPD) Dinas Perhubungan di lingkungan Pemerintahan Kota 
Denpasar. Implikasi yang didapat bahwa; kemampuan pengawas internal dapat meningkatkan pengaruh negatif partisipasi anggaran pada terjadinya senjangan anggaran dengan asumsi bahwa melalui adanya kemampuan pengawas internal atau Aparat Pengawas Internal Pemerintah (APIP) yang baik, maka akan semakin menunjang atau memperkuat tingkat partisipasi anggaran sehingga nantinya akan semakin menurunkan angka/tingkat senjangan anggaran itu sendiri.

Aparat Pengawas Internal Pemerintah (APIP) sangatlah penting keberadaannya dalam proses penyusunan Anggaran Pendapatan dan Belanja Daerah (APBD) demi mencegah terjadinya senjangan anggaran, karnanya diharapkan supaya para pejabat berwenang terkait yang adalah bagian dari Tim Anggaran Pemerintah Daerah (TAPD) dalam Organisasi Perangkat Daerah (OPD) Dinas Perhubungan Pemerintahan Kota Denpasar agar memperhatikan dan melaksanakan secara baik dan benar indikator-indikator serta tahapan-tahapan yang ada/terdapat pada pedoman saat proses penyusunan anggaran di dinas kerja atau instansinya masing-masing, sebelum benar-benar dibahas dan disahkan oleh pihak yang berwenang (DPRD).

Bagi Aparat Pengawas Internal Pemerintah (APIP) juga, agar semakin meningkatkan kinerjanya terkait dengan pengawasan karena peranannya yang juga sangat penting dalam optimalisasi kinerja anggaran dan menekan angka kesenjangan selain oleh variabel partisipasi anggaran dari pegawai pada dinas (OPD) yang bersangkutan. Agar tidak lagi ditemui sistem anggaran tradisional yang terkesan mencari-cari kesalahan (watch dog) dalam proses penyusunan anggaran, melainkan lebih berbasis pada kinerja aktual yang sebenarnya. Disamping itu 
diharapkan agar APIP lebih giat lagi melakukan penyuluhan atau pelatihan kepada tiap-tiap Organisasi Perangkat Daerah (OPD) terkait dengan tahapan-tahapan serta tehnik penyusunan anggaran yang sesuai dengan kaidah-kaidah yang berlaku umum.

\section{REFERENSI}

Allen J, Natalie \& Meyer, John P. (1990). The Measurementand Antecedenta of Affective, Continuance and Normative Comitment to The Organization, Jurnal of Occupational Psychology, Vol. 63

Anthony P. (1989). Manajement Control System, Toponnan Company,Ltd.

Aranya, N., J. Pollock, and J. Amemic. (1981). An Examanation of Professional Commitment in Public Accounting, Accounting Organization and Society, $6(4)$

Arfan Ikhsan dan La Ane (2007). Pengaruh Partisipasi Anggaran Terhadap Senjangan Anggaran Dengan Menggunakan Lima Variabel Pemoderasi Simposium Nasional Akuntansi X, UNHAS Makassar, 26-28 Juli 2007.

Asak, P.Rani Adnyani (2014). "Kemampuan Asimetri Informasi, Ketidakpastian Lingkungan, Budget Emphasis, dan Kapasitas Individu Sebagai Variabel Moderasi Terhadap Partisipasi Anggaran Pada Budgetary Slack (Studi Kasus Pada SKPD di Kabupaten Badung)". "(tesis). Denpasar:Universitas Udayana.

Brownell, P. (1981). Participation in Budgeting, Locus of Control and Organinization Efectivenes, The Accounting Review. Vo;.LVI No.4 October 1981

Brownell, P dan Melnnees. (1986), Budgetary Participation, Motivation and Managerial Performance, The Accounting Rewiev, Vol.LVI No.4

Budi, R. Ikhsan. (2001). Pengaruh Struktur Organisasi dan Locus of Control Terhadap Hubungan Penganggaran Partisipasif Dengan Kinerja Manajerial dan Kepuasan Kerja pada Organisasi Sektor Publik. Tesis. S2., Universitas Gadjah Mada: Yogyakarta

Falikhatun (2007). Interaksi Informasi Asimetri, Budaya Organisasi, dan Group Cohesiveness Dalam Hubungan Antara Partisipasi anggaran dan Budgetary Slack. Simposium Nasional Akuntansi X, UNHAS Makassar, 26-28 Juli 2007. 
Ghozali, Imam. 2013. Aplikasi Analisis Multivariate Dengan Program IBM SPSS 21. Edisi 7. Semarang: Universitas Diponegoro

Gibson, J.L. Ivancevic, J.M., Donnely, Jr. J.H. (2001). Organizational Behavior, Structur and Process. Burr Ridge, Irwin McGraw-Hill.

Gunawan Cahyasumirat (2006). "Pengaruh Profesionalisme dan Komitmen Organisasi terhadap Kinerja Auditor, dengan Kepuasan Kerja sebagai variabel intervening" (tesis). Semarang: Universitas Diponegoro.

Gujarati, D. (2003). Ekonometrika Dasar. (Edisi Bahasa Indonesia). Penerbit Erlangga: Jakarta.

Govindrajan, V. (1986). Impact of Participation in Budgetary Process on Attitudes and Performance: Universalistic and Contingency Perspectives. Fall.

Halim, A. \& Supomo, B. (2000). Akuntansi Manajemen. Edisi Pertama, Cetakan Kesembilan. BPFE: Yogyakarta.

Intan Priliandani, Ni Made (2015). " Pengaruh Partisipasi anggaran Pada Senjangan Anggaran di Universitas Udayana dengan Informasi Asimetri dan Motivasi sebagai Pemoderasi "(tesis). Denpasar:Universitas Udayana.

Mahsun, Mohamad., Sulistyowati, Firma., dan Purwanugraha, H.A. 2007. Akuntansi Sektor Publik. Edisi kedua. Yogyakarta. BPFE.

Novia Hapsari Ardianti, Putu (2015). " Pengaruh Penganggaran Partisipatif pada Budgetary Slack dengan Asimetri Informasi, Self Esteem, Locus of Control dan Kapasitas Individu sebagai Variabel Moderasi (Studi Pada SKPD Kabupaten Jembrana, Bali)". (tesis). Denpasar: Universitas Udayana.

Profesionalisme Auditor, Independensi Auditor, Etika Profesi, Budaya Organisasi, dan Gaya Kepemimpinan terhadap Kinerja Auditor pada Kantor Akuntan Publik di Bali ”(tesis). Denpasar:Universitas Udayana.

Sandrya Dewi, Ni Luh Putu (2013). "Pengaruh Anggaran Partisipatif pada Budgetary Slack dengan Asimetri Informasi, Komitmen Organisasi, Budaya Organisasi dan Kapasitas Individu sebagai variabel moderasi” (tesis). Denpasar: Universitas Udayana.

Schiff. M. dan A.Y. Lewin. (1970). The Impact of People on Budgets. The Accounting Review. April 259-267.

Suartana. (2010). Akuntansi Keperilakuan. CV. Andi: Yogyakarta. 
Febryanto Hardianus Magung dan I Gde Ary Wirajaya. Pengaruh...

Sugiyono. (2015). Statistik Untuk Penelitian. Cetakan Keduapuluhenam. CV. Alfabeta: Bandung.

Sugiyono. (2007). Metode Penelitan Bisnis, Salah Kaprah dan PengalamanPengalaman Cetakan Pertama. BPFE: Yogyakarta.

Supriyatno. (2010). "Pengaruh Partisipasi Pejabat Struktural dalam Penyusunan Anggaran, Komitmen Organisasi, Profesionalisme dan Struktur Organisasi Pada Kinerja Manajerial Pemerintah Kota Denpasar" (tesis). Denpasar: Universitas Udayana. 